Defying Displacement 


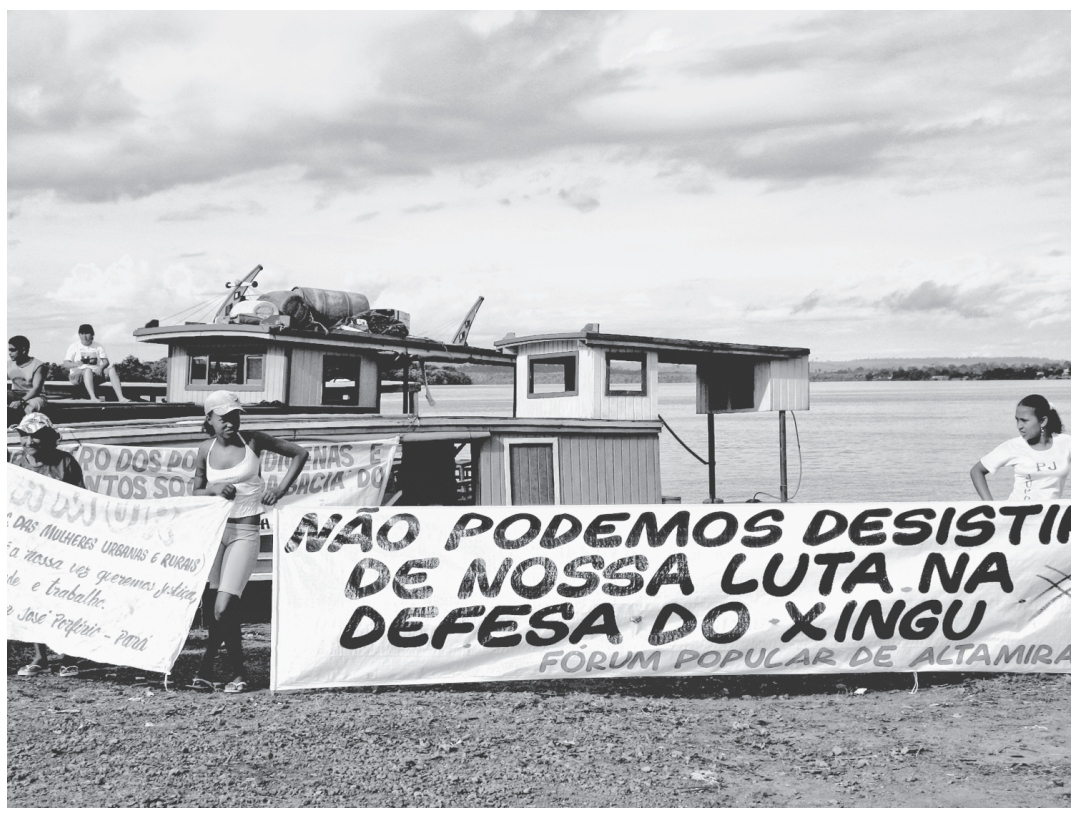

The banner proclaims the determination of residents to continue their protest to protect the Xingu River in Brazil. Photograph by Glenn Switkes 


\section{Defying Displacement}

Grassroots Resistance and the Critique of Development

ANTHONY OLIVER-SMITH

University of Texas Press $\underset{v}{ }$ Austin 
Copyright (C) 20Io by the University of Texas Press

All rights reserved

Printed in the United States of America

First edition, 2010

Requests for permission to reproduce material from this work should be sent to:

Permissions

University of Texas Press

P.O. Box 7819

Austin, TX 78713-7819

www.utexas.edu/utpress/about/bpermission.html

(@) The paper used in this book meets the minimum requirements of ANSI/NISO Z39.48-I992 (RI997) (Permanence of Paper).

\section{Library of Congress Cataloging-in-Publication Data}

Oliver-Smith, Anthony.

Defying displacement : grassroots resistance and the critique of development /

Anthony Oliver-Smith. - Ist ed.

p. $\mathrm{cm}$.

Includes bibliographical references and index.

IS BN 978-0-292-71763-3 (cloth : alk. paper)

I. Forced migration. 2. Land settlement. 3. Protest movements. 4. Infrastructure (Economics)-Social aspects. I. Title.

HV640.045 2010

$325-\mathrm{dc} 22$

2010006152

Portions of Chapter Four are reprinted by permission from Anthony Oliver-Smith, "Evicted from Eden: Conservation and the Displacement of Indigenous and Traditional Peoples," in Development and Dispossession: The Crisis of Forced Displacement and Resettlement, edited by Anthony Oliver-Smith. Copyright (C) 2008 by the School for Advanced Research, Santa Fe, New Mexico. Other materials were previously published in Anthony Oliver-Smith, "Applied Anthropology and DevelopmentInduced Displacement and Resettlement," in Applied Anthropology, edited by Satish Kedia and John van Willigan. Copyright (C) 2005 by Satish Kedia and John van Willigan. Reprinted by permission of Greenwood Publishing Group, Inc., Westport, CT. 